\title{
Improvement of SCP production and BOD removal of whey with mixed yeast culture
}

\author{
Hassan Moeini \\ Department of Biology \\ Faculty of Science \\ Shahid Chamran University \\ Ahvaz, Iran \\ Tel/Fax: 986113331045 \\ E-mail: hamo40@yahoo.com \\ Iraj Nahvi \\ Department of Biology \\ Faculty of Science \\ Isfahan University \\ Isfahan, Iran \\ Tel/Fax: 983117932456 \\ E-mail: I.nahvi@sci.ui.ac.ir \\ Manoochehr Tavassoli \\ Department of Biology \\ Faculty of Science \\ Isfahan University \\ Isfahan, Iran \\ Tel/Fax: 983117932456 \\ E-mail: manoochehrt@yahoo.com
}

Financial support: Isfahan University.

Keywords: $\beta$-galactosidase, BOD, Candida versatilis, Kluyveromyces lactis, Kluyveromyces marxianus, mixed culture, SCP, whey.

\footnotetext{
Abbreviations: SPC: Single Cell Protein;

BOD: Biochemical Oxygen Demand;

MEB: Malt Extract Broth;

YGCA: Yeast extract, Glucose, Chloramphenicol and Agar;

PDA:Potato Dextrose Agar.
}

This research emphasizes on single cell protein (SCP) production and Biochemical Oxygen Demand (BOD) removal from whey with mixed yeast culture. For this purpose, 11 yeast strains were isolated from dairy products (M1-M11) and the strains were identified by morphological and physiological properties. These yeast strains were tested for their ability to reduce the BOD and to produce SCP from whey. Among these strains, K.lactis (M2) had the most SCP production from whey with the yield of $11.79 \mathrm{~g} / \mathrm{l}$. Ammonium sulphate as nitrogen source had an increasing effect on biomass yield. The mixed culture of the isolated yeast strains with Saccharomyces cerevisiae was used in order to increase the biomass yield and BOD removal. The highest biomass yield (22.38 $\mathrm{g} / \mathrm{l})$ and reduction of initial BOD from 30000 to $3450 \mathrm{mg} / \mathrm{l}$ were obtained with the mixed culture of K.lactis (M2) and S. cerevisiae.

Whey is the aqueous fraction of milk generated as a by- product of cheese manufacturing which is produced in large amounts. The main solute in cheese whey is lactose, present at a concentration of about 3-8\% (Speer, 1998). Other components are protein, salts and vitamins that are present in minor amounts. The low concentration of these components makes their recovery uneconomical. Because of it's high organic content with high BOD, whey dumped directly to the environment is causing serious contamination problems (Ben-Hassan and Ghaly, 1994; Roostita and Fleet, 1996; Cristiani-Urbina et al. 2000). As a solution, bioconversion of whey into SCP or ethanol has been performed in several countries (Mawson, 1994; Gonzales Siso, 1996; Grba et al. 2002). The use of whey for the production of yeast biomass has the advantages that it is a simple treatment process, and the final discharge of the whey is facilitated since the pollutant load is significantly reduced and the whey lactose is converted into yeast biomass. The SCP could be produced from whey using yeasts such as Kluyveromyces, Candida and Trichosporon, as they are naturally able to metabolize lactose (Mansour et

\footnotetext{
* Corresponding author
} 


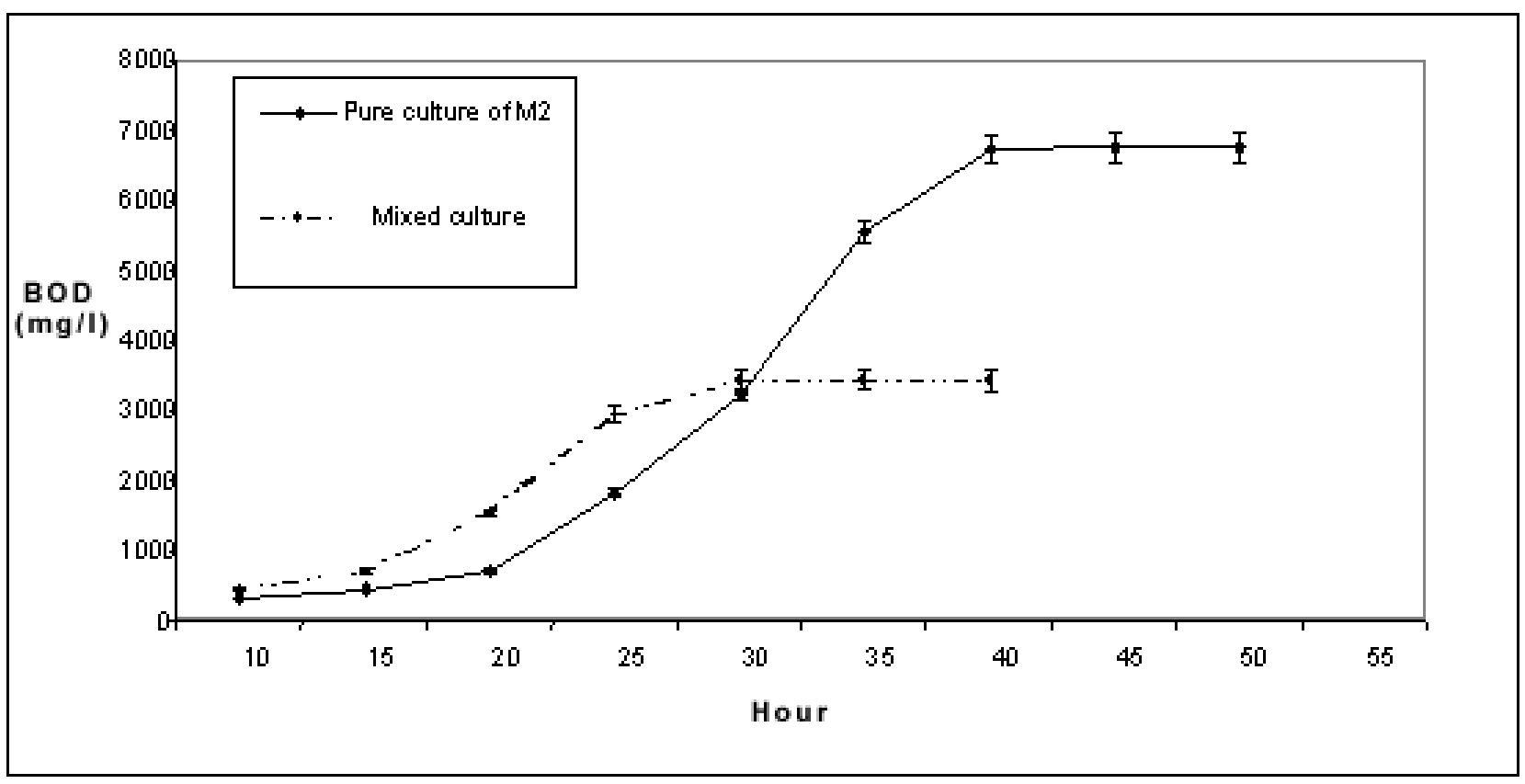

Figure 1. pH BOD removal using pure culture of M2 strain (K. lactis) and mixed culture of M2 strain and S. cerevisiae.

al. 1993). However, it has been observed that in aerated cultures of Kluyveromyces fragilis, K.lactis a change in cellular metabolism from oxidative to a mixed oxidativefermentative state can occurred. This change causes the production of by-metabolic products such as alcohol, aldehydes, esters, etc., which reduce the yields of biomass on whey (Beausejour et al. 1981; Inchaurrondo et al. 1994; Cristiani-Urbina et al. 1997). To avoid this undesirable effect, the mixed yeast culture has been used (Carlotti et al. 1991; Cristiani-Urbina et al. 2000).

The Kluyveromyces species have been most widely studied for SCP production from whey (Moresi et al. 1989; Mansour et al. 1993; Grba et al. 2002). We evaluated the ability of different strains of Kluyveromyces lactis and Kluyveromyces marxianus for consumption of lactose and yeast biomass production. In order to increase the biomass yield and BOD removal of whey, the use of the mixed culture of Kluyveromyces strains and S. cerevisiae is proposed in this research.

\section{MATERIALS AND METHODS}

\section{Sampling and Isolation of yeast strains}

Samples containing whey, yogurt and cheese were collected from dairy producing centers in the City of Isfahan in sterile $200 \mathrm{~mL}$ bottles and brought to the laboratory in a cooler box. For enrichment of yeast samples, $5 \mathrm{~mL}$ (or $5 \mathrm{~g}$ ) of samples were inoculated in $50 \mathrm{~mL}$ of Malt Extract Broth (MEB), containing $0.1 \mathrm{~g} / 1$ chloramphenicol, and incubated at $25^{\circ} \mathrm{C}$ for $24 \mathrm{hrs}$ with constant shaking of $180 \mathrm{rpm}$. After incubation, the existence of yeast cells in media was examined using light microscopy. The media containing yeast cells were then used for isolation of the yeast strains. The yeast strains were isolated on spread plates containing Yeast extract, Glucose, Chloramphenicol and Agar (YGCA). The plates were incubated at $25^{\circ} \mathrm{C}$ for $72 \mathrm{hrs}$. Colonies with distinct morphological differences were selected and purified by streaking on Potato Dextrose Agar (PDA). The purified isolates were stored on PDA slants at $4^{\circ} \mathrm{C}$.

\section{Identification of yeast strains}

To isolate the yeast strains capable of lactose fermentation, the isolated yeasts were cultured in Durham tubes containing $2 \%(\mathrm{w} / \mathrm{v})$ solution of lactose. Then the positive yeast strains for lactose fermentation were identified using the standard taxonomic key (Kurtzman and Fell, 1998). The identification based on different chemical tests including the fermentation of sugars, liquid assimilation of carbon compounds, liquid assimilation of nitrogen compounds, growth at $37^{\circ} \mathrm{C}$ and $40^{\circ} \mathrm{C}$, growth in $50 \%$ glucose and urease.

Fermentation of sugars. Fermentation of lactose, glucose, galactose, sucrose, maltose, raffinose and trehalose were tested in Durham tubes containing 2\% (w/v) solution of sugars, except for raffinose which was $4 \%$. The fermentation basal medium consisted of $4.5 \mathrm{~g}$ yeast extract, $7.5 \mathrm{~g}$ peptone and $20 \mathrm{~g}$ sugar ( $40 \mathrm{~g}$ for raffinose) in $11 \mathrm{of}$ distilled water. The final working medium was made by addition of $4 \mathrm{~mL}$ of Bromothymol blue stock solution (50 
Table 1. $\beta$-galactosidase activity and amount of SCP production in yeast strains.

\begin{tabular}{|c|c|c|c|c|c|c|}
\hline \multirow[b]{2}{*}{ Isolate No. } & \multirow[b]{2}{*}{ Yeast Species } & \multicolumn{2}{|c|}{ Enzyme activity (EU/ml) } & \multicolumn{3}{|c|}{ Biomass yield (g/L) in whey as culture medium } \\
\hline & & YEPD medium & $\begin{array}{l}\text { whey as culture } \\
\text { medium }\end{array}$ & $\begin{array}{c}\text { Without } \\
\text { supplementation }\end{array}$ & $\begin{array}{l}\text { With ammonium sulphate } \\
(0.8 \mathrm{~g} / \mathrm{L})\end{array}$ & $\begin{array}{l}\text { Co-culture of yeast } \\
\text { strains and } S \text {. cerevisiae } \\
+ \text { ammonium sulphate }\end{array}$ \\
\hline M2 & K. lactis & 8103 & 5266 & $11.79 \pm 0.12$ & $15.35 \pm 0.25$ & $22.38 \pm 0.3$ \\
\hline M3 & K. marxianus & 3530 & - & $8.1 \pm 0.2$ & - & - \\
\hline M4 & K. marxianus & 3858 & - & $7.92 \pm 0.19$ & - & - \\
\hline M7 & K. lactis & 1889 & - & $9.41 \pm 0.3$ & $12.83 \pm 0.3$ & - \\
\hline M8 & K. marxianus & 4481 & - & $10 \pm 0.31$ & $13.5 \pm 0.11$ & - \\
\hline M9 & C. versatilis & 3301 & - & $10.19 \pm 0.11$ & $13.69 \pm 0.1$ & - \\
\hline M10 & K. lactis & 2494 & - & $8.73 \pm 0.21$ & $12.1 \pm 0.28$ & - \\
\hline M11 & K. marxianus & 5357 & 4642 & $11.54 \pm 0.1$ & $15.75 \pm 0.14$ & $19.58 \pm 0.2$ \\
\hline
\end{tabular}

$\mathrm{mg} / 75 \mathrm{~mL}$ in distilled water) to $100 \mathrm{~mL}$ fermentation basal medium. The $\mathrm{pH}$ of the medium was adjusted to 7-8. The medium was dispensed into Durham tubes $(4 \mathrm{~mL}$ in each tube). The sterile tubes were inoculated with yeasts from a culture which was $48 \mathrm{hrs}$ old, and incubated at $25^{\circ} \mathrm{C}$ for up to 28 days. The tubes were inspected at frequent intervals. Positive results were indicated by accumulation of gas in Durham tubes, and change of colour in the indicator from dark green to yellow.

Liquid assimilation of carbon and nitrogen compounds. A 10-fold concentrated solution of nitrogen base medium was prepared by dissolving $6.7 \mathrm{~g}$ of bacto yeast nitrogen base, and a carbon source equivalent to $5 \mathrm{~g}$ of glucose in $100 \mathrm{ml}$ of distilled water. In the test tubes 0.5 $\mathrm{ml}$ of the sterile medium was diluted aseptically with $4.5 \mathrm{ml}$ of sterile water. Tubes were then inoculated with cells from a culture which was $24-48 \mathrm{hrs}$ old and incubated at $25^{\circ} \mathrm{C}$ for 2-3 weeks. A positive reaction was detected by visual inspection for an increase in the turbidity of the solution. The carbon compounds tested were galactose, sucrose, maltose, cellulose, trehalose, melibiose, raffinose, inuline, D-xylose, L-arabinose, D-ribose, L-rhamnose, glycerol, Dmannitol, citrate and inositol. The procedure for nitrogen assimilation was similar to the assimilation of carbon compounds test except the yeast nitrogen base was replaced by yeast carbon base (Difco). The nitrogen compounds tested were nitrate and L-lysine.

Other identification tests. To determine the ability of growth at $37^{\circ} \mathrm{C}$ and $40^{\circ} \mathrm{C}$, the yeast strains were cultured in a medium containing $2 \%(\mathrm{w} / \mathrm{v})$ Glucose-Peptone-Yeast extract Broth. The medium was made of $20 \mathrm{~g}$ glucose, $10 \mathrm{~g}$ peptone, and $5 \mathrm{~g}$ yeast extract in 11 of distilled water. The culture medium was inoculated with actively growing yeast culture and incubated at $37^{\circ} \mathrm{C}$ and $40^{\circ} \mathrm{C}$ and $180 \mathrm{rpm}$ for $1-2$ weeks. A positive reaction was detected by observation of turbidity in the solution.

Growth in $\mathbf{5 0 \%}$ glucose and urea hydrolysis tests.
The ability (of the isolated yeast strains) to grow at high concentration of sugar was tested by growth on agar media containing $500 \mathrm{gl}^{-1}$ glucose, $10 \mathrm{gl}^{-1}$ yeast extract and $13 \mathrm{gl}^{-1}$ agar. This medium was sterilized at $110^{\circ} \mathrm{C}$ for $10 \mathrm{~min}$ and dispensed into plates. The plates were inoculated with an actively growing yeast culture and incubated at $25^{\circ} \mathrm{C}$ for 3 4 days. Hydrolysis of urea was examined by using commercially produced Christensen's urea agar base (Merck, Germany). The slant was inoculated from an actively growing yeast culture and incubated at $25^{\circ} \mathrm{C}$ for 4 days. The ability of hydrolysis of urea was detected by development of a pink colour in the slant medium.

\section{Measurement of enzyme activity}

ONPG (O-Nitrophenyl- $\beta$-D-galactopyranoside) assay was applied for calculation of enzyme activity in yeast strains. For this purpose, the strains were inoculated in YGCA medium containing cheese whey and then incubated in $25^{\circ} \mathrm{C}$ for $12-18 \mathrm{hrs}$. The $\mathrm{OD}_{600} \mathrm{~nm}$ was recorded and then 1 $\mathrm{ml}$ of yeast culture was spine out. The yeast cells were washed with $1 \mathrm{ml}$ cold $\mathrm{Z}$ buffer $\left(0.06 \mathrm{M} \mathrm{Na}_{2} \mathrm{HPO}_{4}, 0.04 \mathrm{M}\right.$ $\mathrm{NaH}_{2} \mathrm{PO}_{4}, 0.01 \mathrm{M} \mathrm{KCl}$ and $\left.0.001 \mathrm{M} \mathrm{MgSO}_{4}\right)$. To increase cell permeability, $10 \mu \mathrm{l} 0.1 \%$ SDS and $20 \mu \mathrm{l}$ chloroform was added and incubated in $30^{\circ} \mathrm{C}$ for $10 \mathrm{~min} .200 \mu \mathrm{ONPG}$ solution (4 mg of ONPG in $1 \mathrm{ml}$ potassium phosphate buffer) was added in tubes and time was recorded. The reaction was allowed to run until the solution had turned yellow. The reaction was stopped by addition of $400 \mu \mathrm{l}$ of $1 \mathrm{M} \mathrm{Na} \mathrm{CO}_{3}$ and time was recorded. The cells were spine out, $\mathrm{OD}_{420} \mathrm{~nm}$ of supernatant was read and Miller units were calculated (Units $=1000 \times \mathrm{OD}_{420} /$ volume $(1 \mathrm{ml}) \times$ time (min) $\left.x \mathrm{OD}_{600}\right)$.

\section{SCP production and BOD removal from whey}

From whey without supplementation. The production of SCP was measured on the basis of weight of dry biomass $(\mathrm{g} / \mathrm{l})$ in triplicate. To prevent protein precipitation during heat sterilization, the proteins were eliminated from whey 
as follow: $\mathrm{pH}$ of whey was adjusted to 4.5 and boiled at $100^{\circ} \mathrm{C}$ for $15 \mathrm{~min}$. Whey was cooled and sediment proteins were collected by filtration. One liter of the limpid liquid obtained (greenish yellow) was sterilized at $115^{\circ} \mathrm{C}$ for 10 min and then inoculated by an actively growing culture. The medium was incubated at $25^{\circ} \mathrm{C}$ for $48 \mathrm{hrs}$ with constant shaking $180 \mathrm{rpm}$. After the incubation, the biomass of the yeast cells was prepared by centrifugation at $4000 \mathrm{rpm}$. The biomass was dried and then weighed.

Nitrogen supplementation of whey. We also studied effect of nitrogen supplementation in amount of SCP production with applying ammonium sulphate as the nitrogen source. For this purpose, the whey proteins were removed and then $0.8 \mathrm{~g} / 1$ ammonium sulfate was added. After sterilization at $115^{\circ} \mathrm{C}$ for $10 \mathrm{~min}$, the medium was inoculated by the yeast strains and aired at suitable conditions (see above).

Mixed yeast culture. The best yeast strains were selected and applied as co-culture with S. cerevisiae for treatment of cheese whey and SCP production. For this purpose, the selected strains and $S$. cerevisiae were inoculated into YEPD medium and incubated at $25^{\circ} \mathrm{C}$ for $18-24 \mathrm{hrs}$ with shaking at $200 \mathrm{rpm}$. After preparation of whey, $4 \mathrm{ml}$ of yeast medium was added into the whey medium and it was incubated at conditions mentioned above.

BOD removal in pure and mixed yeast culture. The pure culture of the M2 (K.lactis) and M11 (K. marxianus) was used for Determining Biochemical Oxygen Demand (BOD) removal of whey. For this aim, $200 \mathrm{ml}$ fresh whey was boiled at $100^{\circ} \mathrm{C}$ for $15 \mathrm{~min}$ and denatured proteins were removed and then inoculated by these strains and incubated at $25^{\circ} \mathrm{C}$ for $48 \mathrm{hrs}$ with shaking at $200 \mathrm{rpm}$. After this time, the supernatant was applied for BOD assay with BSB/BOD- sensors. The mixed culture of these strain and S. cerevisiae was also used to study the removal efficiency of BOD from the whey.

\section{RESULTS AND DISCUSSION}

\section{Isolation and identification of yeast strains}

In a search for yeast strains capable of lactose fermentation, 30 different yeast strains were isolated by using MEB containing $0.1 \mathrm{gl}^{-1}$ chloramphenicol and YGCA. Among them, 11 strains were found to ferment lactose (M1-M11). These strains were identified by morphological and physiological properties using the standard taxonomic key outlined by Kurtzman and Fell, 1998. From these, six strains were identified as Kluyveromyces lactis, four strains as Kluyveromyces marxianus and one as Candida versatilis. Comparing to other studies it seems that K.lactis, K. marxianus var. marxianus and its anamorph, C. kefyr, are some of the most predominant and important yeast species in milk (Gadaga et al. 2000). As for the other yeast strains isolated and identified in this study, C. versatilis has been reported in yogurt, cheese and other dairy products (Deak and Beuchat, 1996; Jakobsen and Narvhus, 1996; Gadaga et al. 2000). K. marxianus and K.lactis are used in different biotechnology applications (Shah et al. 1993; Caballero et al. 1995; Gonzales Siso, 1996; Klaus, 1996). The thermotolerance of K. marxianus which was also identified among the isolated yeasts in the present study, could be used in very rapid processes of ethanol production, which might compensate for it's lower tolerance to ethanol compared to $S$. cerevisiae. Among the yeast strains Kluyveromyces fragilis (K. marxianus) have been the most widely studied for the production of yeast biomass from whey (Beausejour et al. 1981; Moresi et al. 1989; Grba et al. 2002) and large-scale processes for producing Kluyveromyces biomass have been in operation for several years (Litchfield, 1983). K.lactis has been used for it's industrial potential in the production of $\beta$-galactosidase enzyme which could be used to reduce the lactose content of milk (Suarez et al. 1995).

\section{$\beta$-galactosidase activity in identified yeasts}

The enzyme lactase, $\beta$-galactosidase, hydrolyzes lactose into glucose and galactose which are more soluble, and sweeter than lactose. This enzyme is produced by many microorganisms that use lactose as energy source (In and Jin, 1998; Uhlig, 1998). Enzyme activity of betagalactosidase in isolated yeast strains was measured (Table 1). Comparing to other studies it seems that the enzyme activity from Kluyveromyces species is higher than other species (Cavaille and Combes, 1995; Inchaurrondo et al. 1998; Santos et al. 1998; Rech et al. 1999). Among isolated yeast strains, the M2 strain (K.lactis) was found to have the highest enzyme activity, 8183 unit $/ \mathrm{ml}$. Also two other strains, M5 (K.lactis) and M11 (K. marxianus) showed high enzyme activity, 5487 and 5357 units $/ \mathrm{ml}$, respectively. In cheese whey, as culture medium, enzyme activities of the M2, M5 and M11 strains were 5266, 5020 and 4642 units $/ \mathrm{ml}$, respectively.

\section{Single cell protein and effect of nitrogen supplementation}

The interest in industrial waste as substrate for SCP production has increased recently. For this purpose the SCP production by the isolated yeast strains and cheese whey as a culture media was next studied. After preparation of cheese whey, inoculation of yeast strains and incubation in suitable temperature, the biomass yield of the pour culture of the isolated yeast strains was detected (Table 1). In whey medium without any supplementation, the M2 (K.lactis), 
M11 (K. marxianus) and M5 (K.lactis) strains had the most SCP production with biomass of $11.79,11.54$ and $11.09 \mathrm{~g} / 1$ dry biomass yield respectively (Table 1). Amount of SCP production can be improved with addition of ammonium sulphate as nitrogen supplementation (Cristiani-Urbina et al. 2000). We found that ammonium sulphate $\left(0.8 \mathrm{gl}^{-1}\right)$ had significant effect on biomass yield (Table 1). The amount of produced biomass of M11 strain increases from $11.54 \mathrm{gl}^{-}$ ${ }^{1}$ in whey without supplementation to $15.75 \mathrm{gl}^{-1}$, in the present of nitrogen supplementation. In this condition, the M11 (K. marxianus) and M2 (K.lactis) strains were found to have the highest biomass yield, 15.75 and $15.35 \mathrm{gl}^{-1}$, respectively.

\section{Improvement of Biomass yield and BOD removal using mixed culture}

Intermediate compounds such as ethanol, esters etc., formed during aerobic growth of K.lactis and K. marxianus, could reduce the yeast biomass yields (Beausejour et al. 1981; Inchaurrondo et al. 1994; Cristiani-Urbina et al. 1997). These intermediate compounds can be metabolized by some other yeast strains. With this regard to increase the biomass yields, the mixed culture of yeast strains has been studied (Carlotti et al. 1991; Cristiani-Urbina et al. 2000). We used mixed culture of isolated yeast strains (M2, M5, M6 and M11) with Saccharomyces cerevisiae for this purpose. Table 1 shows that the biomass yields of the cocultures of the selected strains and $S$. cerevisiae were significantly greater than those of the each strains alone. The biomass yield of $S$. cerevisiae and the M2 strain (K.lactis) co-culture showed a significant increase from 11.79 and $15.35 \mathrm{~g} / \mathrm{l}$ (using pure culture in whey without supplementation and with ammonium sulphate supplementation, respectively) to $22.38 \mathrm{~g} / \mathrm{l}$. The biomass yield obtained in this condition was greater than those reported for K. marxianus (Bainotti et al. 1987), T. cremoris and K. fragilis (Beausejour et al. 1981; Litchfield, 1983; Mansour et al. 1993), for the mixed cultures of K. fragilis, K.lactis, Torulopsis (Pigache et al. 1992) and C. kefyr and C. valida (Carlotti et al. 1991). Increasing demand for protein sources of high nutrition value has stimulated the application of SCP in animal feed. With regards to these results we consider these yeast strains especially in a co-culture to be viable Candidates for production of single cell protein from cheese whey.

We have also, studied the BOD removal using pure cultures of M2 (K.lactis) and M11 (K. marxianus) strains and mixed cultures of these yeast strains with $S$. cerevisiae. When the whey was inoculated by mixed culture of M2 or M11 strains with $S$. cerevisiae, the BOD removal was significantly increased (Figure 1). A greater BOD removal efficiency $(88.5 \%)$ was obtained using mixed culture of M2 strain (K.lactis) and S. cerevisiae, decreasing initial BOD from 30000 to $3450 \mathrm{mgl}^{-1}$. The BOD removal achieved for the mixed culture was greater than those reported for $K$. marxianus (Pigache et al. 1992).

Since the S. cerevisiae can not grow in lactose medium, the results indicate that the $S$. cerevisiae consuming some of the extra cellular metabolites produced during the growth of Kluyveromyces species. In order to demonstrate this ability, the M2 and M1 1 strains were cultured in whey. After $20 \mathrm{hrs}$ incubation at $25^{\circ} \mathrm{C}$ with shaking at $200 \mathrm{rpm}$, the culture medium was filtered through $0.45 \mu \mathrm{m}$ filters under aseptic conditions and the cell free medium was inoculated with $S$. cerevisiae and incubated for $24 \mathrm{hrs}$ at $25^{\circ} \mathrm{C}$ with shaking at $200 \mathrm{rpm}$. The growthwas determined using $\mathrm{OD}_{600}$ (results not shown). As a control, whey medium was inoculated with S. cerevisiae. A significant growth was observed in M2 and M11 filtered culture medium in comparison with the control.

\section{CONCLUDING REMARKS}

The results of this study suggest that yeast strains M2 (K.lactis) and M11 (K. marxianus) could be viable Candidates for SCP and $\beta$-galactosidase production and removal of pollutants, from whey. Also the mixed culture of K.lactis and K. marxianus with S. cerevisiae could be used as an attractive alternative for removal whey BOD and obtaining a valuable biomass yield.

\section{REFERENCES}

BAINOTTI, A.E.; BASILICO, J.C. and CARRASCO DE MENDOZA, M.S. Optimizing conditions for the discontinuous production of unicellular protein using whey. Revista Argentina Microbiologia,1987, vol. 19, p. 1-7.

BEAUSEJOUR, D.; LEDUY, A. and RAMALHO, R.S. Batch cultivation of Kluyveromyces fragilis in cheese whey. Canadian Journal of Chemical Engineering,1981, vol. 59, p. 522-526.

BEN-HASSAN, R.M. and GHALY, A.E. Continuous propagation of Kluyveromyces fragilis in cheese whey for pollution potential reduction. Applied Biochemistry and Biotechnology,1994, vol. 47, p. 89-105.

CABALLERO, R.; OLGUIN, P.; CRUZ-GUERRERO, A.; GALLARDO, F.; GARCIA-GARIBAY, M. and GÓMEZRUIZ, C. Evaluation of Kluyveromyces marxianus as baker's yeast. Food Research International, 1995, vol. 28, no. 1 , p. 37-41.

CARLOTTI, A.; JACOB, F.; PERRIER, J. and PONCET, $S$. Yeast production from crude sweet whey by a mixed culture of Candida kefyr LY496 and Candida valida 
LY497. Biotechnology Letters, 1991, vol. 13, no. 6, p. $437-$ 440.

CAVAILlE, D. and COMBES, D. Characterization of bgalactosidase from Kluyveromyces lactis. Biotechnology and Applied Biochemistry, 1995, vol. 22, no. 1, p. 55-64.

CRISTIANI-URBINA， E.; NETZAHUATL-MUNOZ, A.R.; MANRIQUEZ-ROJAS, F.J.; JUAREZ-RAMIREZ, C.; RUIZ-ORDAZ, N. and GALINDEZ-MAYER, J. Batch and fed-batch cultures for the treatment of whey with mixed yeast cultures. Process Biochemistry, February 2000, vol. 35 , no. 7 , p. 649-657.

CRISTIANI-URBINA, E.; RUIZ-ORDAZ, N. and GALINDEZ-MAYER, J. Differences in the growth kinetic behaviour of Torulopsis cremoris in batch and continuous cultures. Biotechnology and Applied Biochemistry, 1997, vol. 26, no. 3, p. 189-194.

DEAK, T. and BEUCHAT, L.R. Handbook of food spoilage yeasts. Boca Raton, FL: CRC Press, 1996.

GADAGA, T.H.; MYTUKUMIRA, A.N. and NARVHUS, J.A. Enumeration and identification of yeasts isolated from Zimbabwean traditional fermented milk. International Dairy Journal, 2000, vol. 10, no. 7, p. 456-466.

GONZALES SISO, M.I. The biotechnological utilization of cheese whey. A review. Bioresearch Technology, 1996, vol. 57, p.1-11.

GRBA, S.; STEHLIK-TOMAS, V.; STANZER, D.; VAHĚIĚ, N. and ŠKRLIN, A. Selection of yeast strain Kluyveromyces marxianus for Alcohol and Biomass production on Whey. Chemical and Biochemical Engineering Quartery, 2002, vol. 16. no. 1, p. 13-16.

IN, M.J.; JIN, J. Characterization of b-galactosidase from Bacillus sp. with high catalytic efficiency for transgalactosylation. Journal of Microbiology and Biotechnology, 1998, vol. 8, no. 4, p. 318-324.

INCHAURRONDO, V.A.; FLORES, M.V. and VOGET, C.E. Growth and b-galactosidase synthesis in aerobic chemostat cultures of Kluyveromyces lactis. Journal of Industrial Microbiology and Biotechnology, 1998, vol. 20, no. 5, p. 291-298.

INCHAURRONDO, V.A.; YANTORNO, O.M. and VOGET, C.E. Yeast growth and b-galactosidase production during aerobic batch cultures in lactose-limited synthetic medium. Process Biochemistry, 1994, vol. 29. p. 47-54.

JAKOBSEN, M. and NARVHUS, J. Yeasts and their possible beneficial and negative affects on the quality of dairy products. International Dairy Journal, 1996, vol. 6, no. 8-9, p. 755-768.

KURTZMAN, C.P. and FELL, J.W. eds. The Yeasts: A taxonomic study. Elservier: Amsterdam. 1998.

KLAUS, W. editor. No conventional yeasts in biotechnology, A Handbook. Springer-Verlag Berlin Heidelberg New York. 1996, p.139-201.

LITCHFIELD, J.H. Single-cell proteins. Science, 1983, vol. 219, 740-746.

MANSOUR, M.H.; GHALY, A.E; BEN-HASSAN, R.M. and NASSAR, M.A. Modelling batch production of single cell protein from cheese whey. I: Kluyveromyces fragilis growth. Applied Biochemistry and Biotechnology, October 1993, vol. 43, no. 1, p. 1-14.

MAWSON, A.J. Bioconversions for whey utilization and waste abatement. Bioresource Technology, 1994, vol. 47, no. 3, p. 195-203.

MORESI, M.; PATETE, M. and TRUNFIO, A. Scaling-up of a batch whey fermentation by Kluyveromyces fragilis. Applied Microbiology and Biotechnology, 1989, vol. 31, p. 495-501.

PIGACHE, S.; TRYTRAM, G. and DHOMS, P. Oxygen transfer modeling and simulations for an industrial continuous airlift fermentor. Biotechnology and Bioengineering, 1992, vol. 39, no. 9, p. 923-931.

RECH, R.; CASSINI, C.F.; SECCHI, A. and AYUB, M.A.Z. Utilization of protein-hydrolyzed cheese whey for production of b-galactosidase by Kluyveromyces marxianus. Journal of Industrial Microbiology and Biotechnology, 1999, vol. 23, no. 2, p. 91-93.

ROOSTITA, R.; and FLEET, G.H. Growth of yeasts in milk and associated changes to milk composition. International Journal of Food Microbiology, 1996, vol. 31, p. 215-219.

SANTOS, A.; LADERO, M. and GARCIA-OCHOA, F. Kinetic modeling of lactose hydrolysis by a b-galactosidase from Kluyveromyces fragilis. Enzyme and Microbial Technology, 1998, vol. 22, no. 7, p. 558-567.

SHAH, N.P.; SPURGEON, K.R. and GILMORE, T.M. Use of dry whey and lactose hydrolysis in yogurt bases. Milk Science International, 1993, vol. 48, no. 9, p. 494-498.

SPEER, E. Milk and dairy product technology. New York: 
Moeini, H. et al.

Marcel Dekker, 1998.

SUAREZ, F.L.; SAVAIANO, D.A. and LEVITT, M.D. Review article: The treatment of lactose intolerance. Alimentary Pharmacology and Therapeutics, December 1995, vol. 9, no. 6, p. 589-597.

UHLIG, H. Industrial enzymes and their applications. Translated and updated by Elfriede, M. and Bednar, L., John Wiley and Sons, Inc., 1998. 